\title{
Multiple tobacco use among young adult waterpipe smokers in Egypt
}

Aya Mostafa ${ }^{1}$, Moustafa El Houssinie ${ }^{1}$ and Aisha Aboul Fotouh ${ }^{1}$

${ }^{1}$ Department of Community, Environmental and Occupational Medicine, Faculty of Medicine, Ain Shams University, Cairo, Egypt (Correspondence to Aya Mostafa: aya.kamaleldin@med.asu.edu.eg).

\begin{abstract}
Background: The use of multiple tobacco products is an emerging trend. Studies on multiple use among waterpipe smokers are limited.

Objectives: We aimed to estimate the proportion of other tobacco products used by current adult waterpipe smokers in Egypt and identify the determinants of multiple tobacco product use.

Methods: Population-based surveys were conducted using interview questionnaires during 2015-2017 in urban Cairo and rural Menoufia. Participants aged 18 years and older were selected using purposive quota non-random sampling. The total sample included 2014 participants. We analysed the data on 1490 current waterpipe smokers. Variables recorded included: tobacco use, health beliefs, waterpipe smoking behaviour, sociodemographic characteristics, and perceived effectiveness of pictorial health warnings on waterpipe tobacco packs. Current waterpipe smokers were classified as waterpipe-only users and multiple tobacco product users.

Results: Almost half (47.9\%) of the current waterpipe smokers used multiple tobacco products; $93.4 \%$ were dual users and $6.6 \%$ poly-users. The other tobacco products used were cigarettes ( $86.4 \%$ ), electronic nicotine delivery systems (ENDS) (7.0\%) or both $(6.6 \%$ ). Multiple users were more likely to be younger than waterpipe-only users. Young adult female waterpipe smokers used ENDS 12 times more than young adult males (48.8\% versus $4.1 \%$ respectively). Non-daily waterpipe smoking, usually smoking at cafes, higher education and knowledge of pictorial health warnings were independent predictors of multiple tobacco product use.
\end{abstract}

Conclusion: Multiple tobacco product use was common among current waterpipe smokers in our study. Interventions to tackle non-cigarette and multiple tobacco use, especially in young adults, are urgently needed.

Keywords: waterpipe;tobacco; multiple use; young adults; e-cigarettes/ electronic nicotine delivery systems

Citation: Mostafa A, El Houssine M, Fotouh A. Multiple tobacco use among young adult waterpipe smokers in Egypt. East Mediterr Health J. 2018;24(1):7-17. https://doi.org/10.26719/2018.24.1.17

Received: 15/09/17; accepted: 21/11/17

Copyright (c) World Health Organization (WHO) 2018. Some rights reserved. This work is available under the CC BY-NC-SA 3.0 IGO license (https:// creativecommons.org/licenses/by-nc-sa/3.o/igo)

\section{Introduction}

Tobacco use is a risk factor of the main noncommunicable diseases that cause $80 \%$ of premature global mortality $(1,2)$. Most of the world's smokers live in low- and middleincome countries, and $80 \%$ of the projected 8 million annual tobacco-related deaths by 2030 will occur in these countries (3). Therefore, tobacco control is one of the sustainable development goals for prevention and control of the noncommunicable diseases (4).

In the past few years, a trend in multiple or concurrent use of tobacco products has emerged (5-13). Growing evidence on the health hazards of the use of non-cigarette or other tobacco products has been reported (14-16). In Egypt, treatment of tobacco-related diseases costs US\$ 616 million annually, while 170000 deaths attributable to tobacco occur each year (17). The use of multiple tobacco products may increase this health and economic burden, and prevent the achievement of the global target of a $30 \%$ relative reduction in tobacco use by 2025 (2).

The reported rates of multiple tobacco product use are high. A large national study in the United States of
America (USA) found that $40 \%$ of both adult and youth tobacco users used multiple tobacco products, mostly combining cigarettes and e-cigarettes (10). However, cigarette smoking is not always included in multiple tobacco use combinations (12). Waterpipe tobacco smoking, smokeless tobacco and electronic nicotine delivery systems (ENDS) are increasingly used worldwide $(5,7,8,12,13,18,19)$, and have been promoted as less harmful alternatives to cigarettes $(20,21)$. Young people who use multiple tobacco products are more prone to nicotine dependence and to continue using tobacco as adults (22). In the USA, about half of young current tobacco product users used 2 or more tobacco products (23). In the Eastern Mediterranean region, adolescents used other tobacco products (mainly waterpipe) more frequently than cigarettes (24). However, other tobacco products are not all regulated by national tobacco control laws (25).

Egypt has one of the highest rates of tobacco use in the Eastern Mediterranean region (26). Nearly half of Egyptian men currently smoke cigarettes or other tobacco products - most of them smoke daily - compared with $0.2 \%$ of women (27). Young adult males use tobacco in 
similarly high proportion (40.5\%) (27). Tobacco smoking is projected to increase to $62.9 \%$ among men in Egypt by 2025 (28). Also, young women in Egypt are using tobacco more, particularly non-cigarette tobacco products (29). In the 2005 and 2009 Global Youth and Global Adult Tobacco Surveys, Egyptian adolescent girls were 11 times more likely to smoke waterpipe tobacco than adult women and reported a higher prevalence of overall use of any tobacco product $(3.8 \%)$ than older females $(0.3 \%)$ (29). Studies determining the magnitude of multiple use of tobacco products among waterpipe smokers are limited. The aim of our study therefore was to estimate the proportion of other tobacco use among adult waterpipe smokers in Egypt, and to identify the factors associated with the use of multiple tobacco products.

\section{Methods}

Data for this study were collected as part of a larger study on the effectiveness of pictorial health warnings on waterpipe tobacco packs in encouraging cessation and preventing initiation of waterpipe tobacco smoking in Egypt.

\section{Study design and sample}

The larger study consisted of 2 cross-sectional, population-based surveys conducted in July-November 2015 and September 2016-January 2017. The target sample included 1025 individuals in each survey period and consisted of male and female waterpipe smokers and nonsmokers aged 18 years and older from urban Cairo and a rural village in Menoufia governorate. Participants were selected using a purposive quota non-random sampling scheme. Trained field interviewers approached individuals at cafes, homes, workplaces and universities. Researches explained the purpose of the study before they screened individuals for age eligibility. Individuals who agreed to participate in the study provided their voluntary informed verbal consent to respond to a 25-minute face-to-face interview questionnaire. Participants were assigned an identification number for anonymity and to ensure confidentiality of their data. The total targeted sample in the 2 surveys of the parent study was 2050 and the final sample included 2014 participants (response rate $98.2 \%)$; of these, 1490 (73.9\%) were current waterpipe smokers.

\section{Data collected}

In this study, we analysed a subset of data from the larger study that focused on the current waterpipe smokers. Data included were respondents': tobacco use, sociodemographic characteristics, exposure to household second-hand smoke, health beliefs about waterpipe tobacco smoking, waterpipe smoking behaviour, and perceived effectiveness of pictorial health warnings on waterpipe tobacco packs.

For tobacco use, we considered 3 types of tobacco products: waterpipe, cigarettes, and electronic nicotine delivery systems (ENDS) - e-shisha or e-cigarettes. Respondents were defined as current smokers if they had used any of the 3 tobacco products in the past 30 days (30); otherwise they were considered a nonsmoker (Figure 1). The main outcome studied was the sole use of waterpipe tobacco or the use of waterpipe tobacco in combination with other tobacco products. We defined a waterpipeonly user as a participant who currently smoked waterpipe tobacco only and did not concurrently use any other tobacco product. A multiple user was defined as a participant who currently smoked waterpipe tobacco as well as one or more other tobacco product - cigarettes or ENDS (dual user), or both (poly-user). The frequency of waterpipe tobacco smoking was measured as daily, weekly or monthly; cigarette smoking as daily or nondaily; and ENDS smoking as any use. Data on duration of use were available only for waterpipe tobacco smoking.

Sociodemographic data collected were: age, gender, residence (urban/rural), marital status, educational attainment and occupation. Data were also collected on participants' household exposure to second-hand smoke from cigarettes or waterpipe or both, and their beliefs about the effect of waterpipe tobacco smoking on health - whether they considered waterpipe smoking and the nicotine content of waterpipe tobacco were less, more, or equally hazardous compared with cigarette smoking and cigarette tobacco. To assess the waterpipe smoking behaviour of the participants, data were collected on: age at starting smoking waterpipes, preferred type of waterpipe tobacco (plain, flavoured), usual place to smoke waterpipes, average daily spending on waterpipe smoking, and previous attempts to stop smoking waterpipes. To evaluate the effectiveness of pictorial health warnings on waterpipe tobacco packs, data were collected on knowledge of pictorial health warnings on waterpipe tobacco packs, discussion of pictorial health warnings with others, and change induced in waterpipe smoking behaviour - e.g. smoked fewer hagar (portion of tobacco), had foregone a smoke, was more likely to consider quitting waterpipe smoking.

\section{Statistical analysis}

We described the sociodemographic characteristics of the participants and the proportions of tobacco users in the total sample $(n=2$ 014) and in the subset of 1490 current waterpipe smokers. We categorized current waterpipe smokers into waterpipe-only users and multiple users and compared them according to sociodemographic characteristics using the chi-squared test for categorical variables. A $P$-value $<0.05$ was considered statistically significant. The frequency of both waterpipe and cigarette smoking was further analysed as daily and non-daily use. Data on the frequency of ENDS use were insufficient; therefore the amount consumed was reported only for multiple users who were using both waterpipes and cigarettes.

Univariate analysis was used to identify variables associated with multiple tobacco product use among current waterpipe smokers. Variables that were statistically significantly associated with multiple use in the univariate analysis were included in a multivariable 
logistic regression analysis. Adjusted odds ratios $\left(\mathrm{OR}_{\mathrm{a}}\right)$ and $95 \%$ confidence intervals (CI) are reported. Variables included were gender, age, educational attainment, marital status, household exposure to second-hand smoke, frequency of waterpipe smoking, age at starting waterpipe smoking, place to smoke waterpipes, beliefs about the health effects of waterpipe smoking, knowledge of pictorial health warnings on waterpipe tobacco packs, discussion of pictorial health warnings with others, and effect of pictorial health warnings on participants' waterpipe smoking behaviour.

Data were analysed using the SPSS, version 22.

\section{Ethical considerations}

The study was approved by the Ethical Review Board of the Faculty of Medicine, Ain Shams University, Cairo, Egypt.

\section{Results}

\section{Tobacco use in the total sample}

More than three-quarters (79.1\%) of our total sample $(n=2014)$ currently used a tobacco product; waterpipe tobacco $(74.0 \%)$, cigarettes (37.6\%) or ENDS (5.5\%) - as sole use $(55.1 \%)$ or in combination with other tobacco products (44.9\%) (Figure 1). As we intended to recruit an equal number of waterpipe smokers by age group, gender, and rural/urban residence, the distribution of waterpipe smokers in the total sample did not vary significantly between these demographic groups.

Cigarettes were significantly more likely to be used by younger adults $(43.6 \%$ versus $34.1 \%$ by older adults, $P$ $<0.001$ ), males (38.5\% versus $29.4 \%$ by females, $P=0.013$ ), and those living in rural areas ( $43.1 \%$ versus $29.5 \%$ in urban areas, $P<0.001)$. Of the total smokers, female participants

Figure 1 Current tobacco use among study participants showing total, sole and multiple tobacco product use - waterpipes, cigarettes and electronic nicotine delivery systems (ENDS)

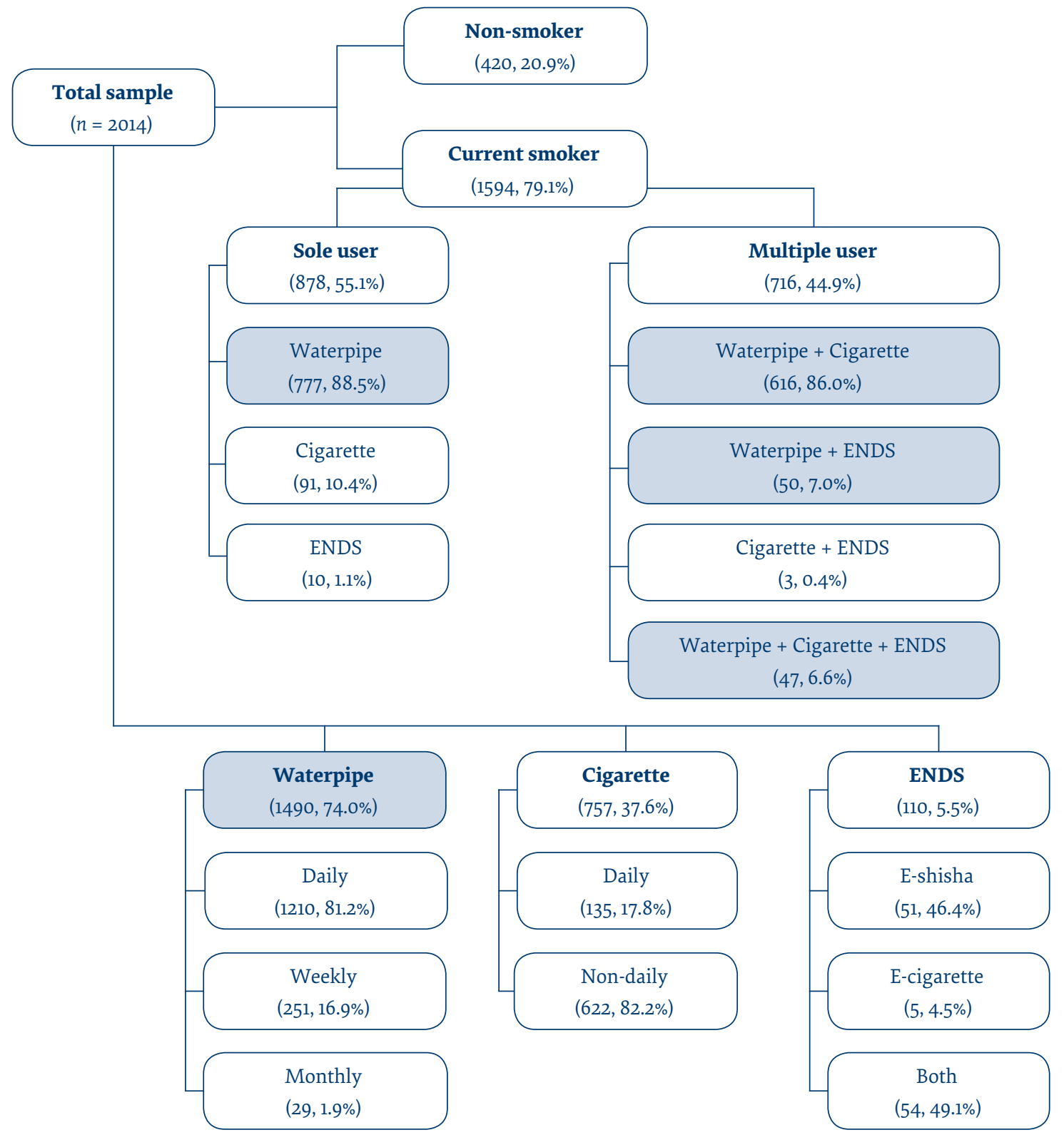


reported using ENDS 9 times more than males (27.8\% versus $3.1 \%$ respectively, $P<0.001$ ). Of the waterpipe smokers, females reported using ENDS 12 times more than males (40.3\% versus $3.3 \%$ respectively, $P<0.001$ ).

Tobacco use among current waterpipe smokers (n = 1490)

Almost half ( $n=713,47.9 \%$ ) of the 1490 current waterpipe smokers were multiple tobacco product users. Of the multiple users, 666 (93.4\%) were dual users; only 47 (6.6\%) were poly-users. Cigarettes were the main tobacco product of the other tobacco products used by multiple users $(616,86.4 \%)$ while the rest of the multiple users smoked ENDS (50,7.0\%) or both cigarettes and ENDS (47, 6.6\%) (Figure 1, blue shaded boxes).

Multiple users were significantly more likely to be younger than waterpipe-only users $(P<0.001)$. Among females, the use of multiple tobacco products was significantly more common than waterpipe-only use (60.4\% versus $39.5 \%$ respectively) $(P=0.003)$ (Figure 2 ). Moreover, just over half of the younger adult females who smoked waterpipes reported using ENDS as the other tobacco product (51.2\%), compared with $36.0 \%$ in the older female age group, and $4.1 \%$ and $2.9 \%$ respectively in their male counterparts.
Table 1 shows the demographic characteristics and household exposure to smoking of the total sample ( $n=2$ 014) and current waterpipe smokers ( $n=1490)$ categorized as users of the waterpipe only and users of multiple tobacco products. Significantly more multiple users had secondary or higher education than waterpipeonly users, and were unmarried $(P<0.001)$. No statistically significant differences were found between waterpipeonly users and multiple users for occupation or rural/ urban residence. More than two thirds (1 009/1 490, 67.7\%) of all waterpipe smokers reported exposure to secondhand smoke at home. This exposure was significantly higher among multiple users than waterpipe-only users (71.2\% versus $64.5 \%$ respectively, $P=0.006$ ).

Waterpipe tobacco smoking behaviour and health beliefs

Table 2 shows the behaviour and health beliefs of waterpipe-only users compared with multiple tobacco product users. Significantly more waterpipe-only smokers were daily smokers, while more multiple users were non-daily waterpipe smokers $(P<0.001)$. Among multiple users, significantly more females were non-daily waterpipe smokers (70.5\% versus $29.5 \%$ daily smokers) than males (19.5\% versus $80.5 \%$ daily smokers $)(P<0.001)$.

Figure 2 Sole use of waterpipe tobacco and type of other tobacco product used among waterpipe smokers by gender and age-group (WTS: waterpipe tobacco smoking; ENDS: electronic nicotine delivery systems)

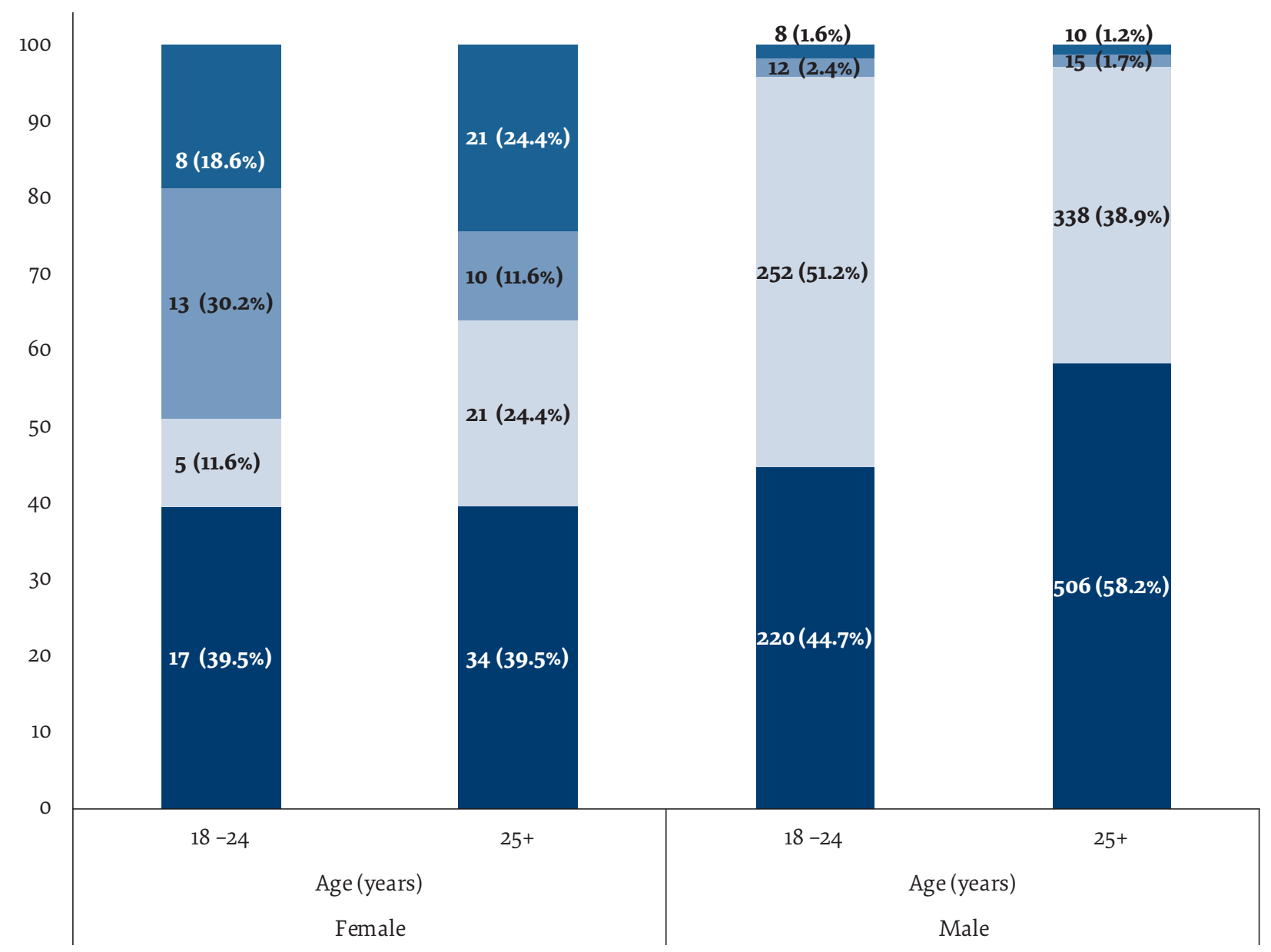

WTS only WTS + Cigarette WTS + ENDS $\square$ WTS + Cigarette + ENDS 


\begin{tabular}{|c|c|c|c|c|}
\hline \multirow[t]{2}{*}{ Characteristic } & \multirow{2}{*}{$\begin{array}{l}\text { Total sample } \\
(n=2014)\end{array}$} & \multicolumn{2}{|c|}{ Current waterpipe smokers } & \multirow[t]{2}{*}{ P-value ${ }^{a}$} \\
\hline & & $\begin{array}{l}\text { Waterpipe-only user } \\
\qquad(n=777)\end{array}$ & $\begin{array}{l}\text { Multiple tobacco } \\
\text { product user }(n=713)\end{array}$ & \\
\hline & No. $(\%)$ & No. $(\%)$ & No. (\%) & \\
\hline \multicolumn{5}{|l|}{ Age group (years) } \\
\hline $18-24$ & $743(36.9)$ & $237(30.5)$ & $298(41.8)$ & \multirow[t]{2}{*}{$<0.001$} \\
\hline $25^{+}$ & $1271(63.1)$ & $540(69.5)$ & $415(58.2)$ & \\
\hline \multicolumn{5}{|l|}{ Gender } \\
\hline Male & $1820(90.4)$ & $726(93.4)$ & $635(89.1)$ & \multirow[t]{2}{*}{0.003} \\
\hline Female & $194(9.6)$ & $51(6.6)$ & $78(10.9)$ & \\
\hline \multicolumn{5}{|l|}{ Residence } \\
\hline Rural & $1194(59.3)$ & $442(56.9)$ & $441(61.9)$ & \multirow[t]{2}{*}{0.051} \\
\hline Urban & $820(40.7)$ & $335(43.1)$ & $272(38.1)$ & \\
\hline \multicolumn{5}{|l|}{ Education } \\
\hline No schooling & $90(4.5)$ & $53(6.8)$ & $22(3.1)$ & \multirow{5}{*}{$<0.001$} \\
\hline Primary & $139(6.9)$ & $82(10.6)$ & $36(5.0)$ & \\
\hline Preparatory & $163(8.1)$ & $91(11.7)$ & $48(6.7)$ & \\
\hline Secondary & $679(33.7)$ & $248(31.9)$ & $306(42.9)$ & \\
\hline Vocational/university & $943(46.8)$ & $303(39.0)$ & $301(42.2)$ & \\
\hline \multicolumn{5}{|l|}{ Occupation $^{b}$} \\
\hline Professional & $314(15.6)$ & $95(12.2)$ & $94(13.2)$ & \multirow{5}{*}{0.928} \\
\hline Technicians and associate professionals & $203(10.1)$ & $69(8.9)$ & $65(9.1)$ & \\
\hline Skilled & $838(41.6)$ & $371(47.7)$ & $328(46.0)$ & \\
\hline $\begin{array}{l}\text { Elementary occupations (e.g. porters, door } \\
\text { keepers) }\end{array}$ & $189(9.4)$ & $84(10.8)$ & $73(10.2)$ & \\
\hline Student/unemployed & $470(23.3)$ & $158(20.3)$ & $153(21.5)$ & \\
\hline \multicolumn{5}{|l|}{ Marital status } \\
\hline Unmarried & $743(36.9)$ & $233(30.0)$ & $294(41.2)$ & \multirow[t]{2}{*}{$<0.001$} \\
\hline Married & $1271(63.1)$ & $544(70.0)$ & $419(58.8)$ & \\
\hline \multicolumn{5}{|l|}{ Someone at home smokes } \\
\hline Yes & $1272(63.2)$ & $501(64.5)$ & $508(71.2)$ & 0.006 \\
\hline Waterpipe & $212(16.7)$ & $92(18.4)$ & $68(13.4)$ & 0.151 \\
\hline Cigarettes & $344(27.0)$ & $96(19.1)$ & $127(25.0)$ & 0.004 \\
\hline Both & $716(56.3)$ & $313(62.5)$ & $313(61.6)$ & 0.172 \\
\hline
\end{tabular}

${ }^{a}$ Comparison between users of the waterpipe only and users of multiple tobacco products.

${ }^{b}$ Adapted from the International Standard Classification of Occupations (http://www.ilo.org/public/english/bureau/stat/isco/iscoo8/index.htm)

More multiple users started smoking waterpipes at an older age than waterpipe-only users $(P<0.001)$. More females started smoking waterpipes at 18 years or older compared with males (88.5\% versus $53.5 \%$ respectively) $(P<0.001)$. Significantly more multiple users, especially young adults $(P=0.018)$ and females $(P<0.001)$, smoked waterpipes at cafes, while waterpipe-only users smoked at home and in cafes alike (Table 2). Females spent 4 times as much on waterpipe tobacco smoking than males - median daily spending = 16 EGP (interquartile range 10-30 EGP) for females compared with 4 EGP for males (interquartile range 3-10 EGP). Young adult females were significantly more likely to smoke flavoured waterpipe tobacco $(76.7 \%)$ than older females $(65.1 \%)$ and their male counterparts (12.4\%) $(P<0.001$ for both).
The majority of waterpipe-only and multiple users (60.4\% and $65.1 \%$ respectively) believed that waterpipe smoking was bad for health but only about one-fifth of both waterpipe-only users (20.1\%) and multiple users (19.1\%) ever tried to quit (Table 2). These beliefs were significantly higher among young adult male waterpipe smokers $(P<0.001)$.

Significantly more multiple users were aware of the pictorial health warnings on waterpipe tobacco packs than waterpipe-only users $(P<0.001)$. This was highest among young adult males (80.4\%). Among females, older adult waterpipe-only users were more aware of pictorial health warnings (35.3\%) than younger females $(29.4 \%)(P=$ 0.019). Of those who knew about pictorial warnings, more multiple users discussed them often compared with 
waterpipe-only users $(P<0.001)$ (Table 2$)$, especially older males. Among females, only older adult waterpipe-only users reported that they often discussed pictorial health warnings.

Among those who knew of the pictorial health warnings, multiple users were significantly more likely than waterpipe-only users to have changed their waterpipe tobacco smoking habit (reduced the number of hagar smoked, $P=0.025$; foregone a smoke, $P<0.001$; and considered quitting waterpipe smoking, $P=0.006$ ) because of the warnings (Table 2). This change was more common in males $(48.5 \%$ versus $10.1 \%$ of females,

\begin{tabular}{|c|c|c|c|}
\hline Variable & $\begin{array}{l}\text { Waterpipe-only user } \\
\qquad(\mathbf{n}=\mathbf{7 7 7})\end{array}$ & $\begin{array}{l}\text { Multiple tobacco product } \\
\text { user }(n=713)\end{array}$ & P-value \\
\hline & No. $(\%)$ & No. $(\%)$ & \\
\hline \multicolumn{4}{|l|}{ Smokes waterpipe } \\
\hline Monthly & $16(2.1)$ & $13(1.8)$ & \\
\hline Weekly & $85(10.9)$ & $166(23.3)$ & $<0.001$ \\
\hline Daily & $676(87.0)$ & $534(74.9)$ & \\
\hline \multicolumn{4}{|l|}{ Age when started waterpipe smoking (years) } \\
\hline $11-17$ & $419(53.9)$ & $304(42.6)$ & $<0.001$ \\
\hline $18+$ & $358(46.1)$ & $409(57.4)$ & \\
\hline \multicolumn{4}{|l|}{ Place where usually smoke waterpipe } \\
\hline Cafe/restaurant & $309(39.8)$ & $384(53.9)$ & \\
\hline Home & $319(41.1)$ & $155(21.7)$ & $<0.001$ \\
\hline Other & $149(19.2)$ & $174(24.4)$ & \\
\hline \multicolumn{4}{|l|}{ Type of waterpipe tobacco smoked } \\
\hline Plain & $622(80.1)$ & $555(77.8)$ & \\
\hline Flavoured & $135(17.4)$ & $126(17.7)$ & 0.125 \\
\hline Both & $20(2.6)$ & $32(4.5)$ & \\
\hline \multicolumn{4}{|l|}{ Believes effects of smoking waterpipe tobacco on health are: } \\
\hline Good & $124(16.0)$ & $53(7.4)$ & \\
\hline Neither good nor bad & $146(18.8)$ & $165(23.1)$ & $<0.001$ \\
\hline Bad & $469(60.4)$ & $464(65.1)$ & \\
\hline Don't know & $38(4.9)$ & $31(4.3)$ & \\
\hline \multicolumn{4}{|l|}{$\begin{array}{l}\text { Believes the harmful effects of smoking waterpipe tobacco } \\
\text { compared to smoking cigarettes are: }\end{array}$} \\
\hline Fewer & $128(16.5)$ & $115(16.1)$ & \\
\hline The same & $184(23.7)$ & $145(20.3)$ & 0.021 \\
\hline More & $403(51.9)$ & $417(58.5)$ & \\
\hline Don't know & $62(8.0)$ & $36(5.0)$ & \\
\hline \multicolumn{4}{|l|}{$\begin{array}{l}\text { Believes the nicotine content of waterpipe tobacco compared } \\
\text { to cigarette tobacco is: }\end{array}$} \\
\hline Lower & $135(17.4)$ & $99(13.9)$ & \\
\hline The same & $122(15.7)$ & $123(17.3)$ & $<0.001$ \\
\hline Higher & $273(35.1)$ & $342(48.0)$ & \\
\hline Don’t know & $247(31.8)$ & 149 (20.9) & \\
\hline Ever tried to quit, yes & $156(20.1)$ & $134(18.9)$ & 0.551 \\
\hline $\begin{array}{l}\text { Aware of pictorial health warnings on waterpipe tobacco } \\
\text { packs, yes }\end{array}$ & $471(60.6)$ & $503(70.5)$ & $<0.001$ \\
\hline $\begin{array}{l}\text { Discussed pictorial health warnings on waterpipe tobacco } \\
\text { packs with others, often }{ }^{\text {a }}\end{array}$ & 130/459 (28.3) & 189/492 (38.4) & 0.001 \\
\hline $\begin{array}{l}\text { Pictorial health warnings on waterpipe tobacco packs } \\
\text { changed waterpipe smoking habit }{ }^{a}\end{array}$ & $(n=459)$ & $(n=492)$ & \\
\hline Reduced hagar & $276(60.1)$ & $337(68.5)$ & 0.025 \\
\hline Forgone a smoke & $164(35.7)$ & $237(48.2)$ & $<0.001$ \\
\hline More likely to consider quitting & $244(53.2)$ & $312(63.4)$ & 0.006 \\
\hline
\end{tabular}

"These questions were answered only by those who responded "yes" to "Aware of pictorial health warnings on waterpipe tobacco packs"; a few responses were missing. 
$P<0.001)$ and young adults $(51.4 \%$ versus $41.7 \%$ of older adults, $P<0.001)$.

\section{Predictors of multiple tobacco product use}

The results of the univariate and multiple logistic regression analyses are shown in Table 3. Of the variables found significantly associated with multiple use among current waterpipe smokers in the univariate analysis, the following remained statistically significant in the logistic regression analysis: non-daily waterpipe smoking (OR $=1.5,95 \%$ CI: 1.09-2.07), cafes being the usual place of smoking $\left(\mathrm{OR}_{\mathrm{a}}=1.87,95 \% \mathrm{CI}\right.$ : 1.43-2.44), higher educational attainment (high school/university education) $\left(\mathrm{OR}_{\mathrm{a}}=\right.$ 1.81, 95\% CI: 1.34-2.43), and knowledge of pictorial health warnings on waterpipe tobacco packs $\left(\mathrm{OR}_{\mathrm{a}}=2.29,95 \% \mathrm{CI}\right.$ : 1.65-3.17).

Often discussing pictorial health warnings on waterpipe tobacco packs with others and considering changing waterpipe smoking habit because of the pictorial health warnings were highly correlated with knowledge of pictorial health warnings and so were removed from the analysis. A confounding effect of age and gender in relation to age at starting waterpipe smoking, marital status and educational level was observed; there were more females than males in the categories higher educational attainment, unmarried and late start of waterpipe smoking.

\section{Discussion}

Multiple tobacco product use was common among current waterpipe smokers in our participants. Almost half of them were either dual users or poly-users. These findings concur with the recent evidence from both highand low/middle-income countries $(5,6,13)$ that multiple tobacco product use is increasing, reaching up to $40 \%$ or more among both adult and youth current tobacco users $(8-11,23)$.

However, the estimates reported for multiple use among current tobacco users vary widely $(0.5 \%-66.2 \%)$ depending on the type of tobacco (smoked or smokeless) studied $(5,7,12,19)$. The term "multiple tobacco product use" has only recently been used in the literature and has appeared mainly in studies done in the USA $(6,9,11,31)$. "Poly-use", "dual use", "other tobacco products", "noncigarette tobacco" and "alternative tobacco products" are terms that have been more often reported to indicate the use of more than one tobacco product. However, these terms have different definitions (32).

Notably, we found that young adult females used multiple tobacco products more often than males, which differs from the reported gender profile of multiple users from other countries $(9,11)$. However, results from previous studies indicate a change in social and cultural smoking norms among women in Egypt, as use of both cigarettes and other tobacco products is increasing, especially among adolescents (29). Not only is the difference in smoking between youth and adult females closing (29), but the gender gap for waterpipe tobacco smoking is also narrowing, a finding reported in other countries in the region as well (33). Consistent with previous reports, the other tobacco product used by current waterpipe smokers in our study was mostly cigarettes $(10,19)$. ENDS use was more common among young adult female waterpipe smokers in our study. Similarly, e-cigarettes were commonly used by multiple users in other studies $(6,8,12,13)$. The use of non-cigarette products among cigarette smokers is thought to be an attempt to quit (20-22) but there are concerns that they may serve as an entry to cigarette use in young people (34). However, we did not examine the order in which

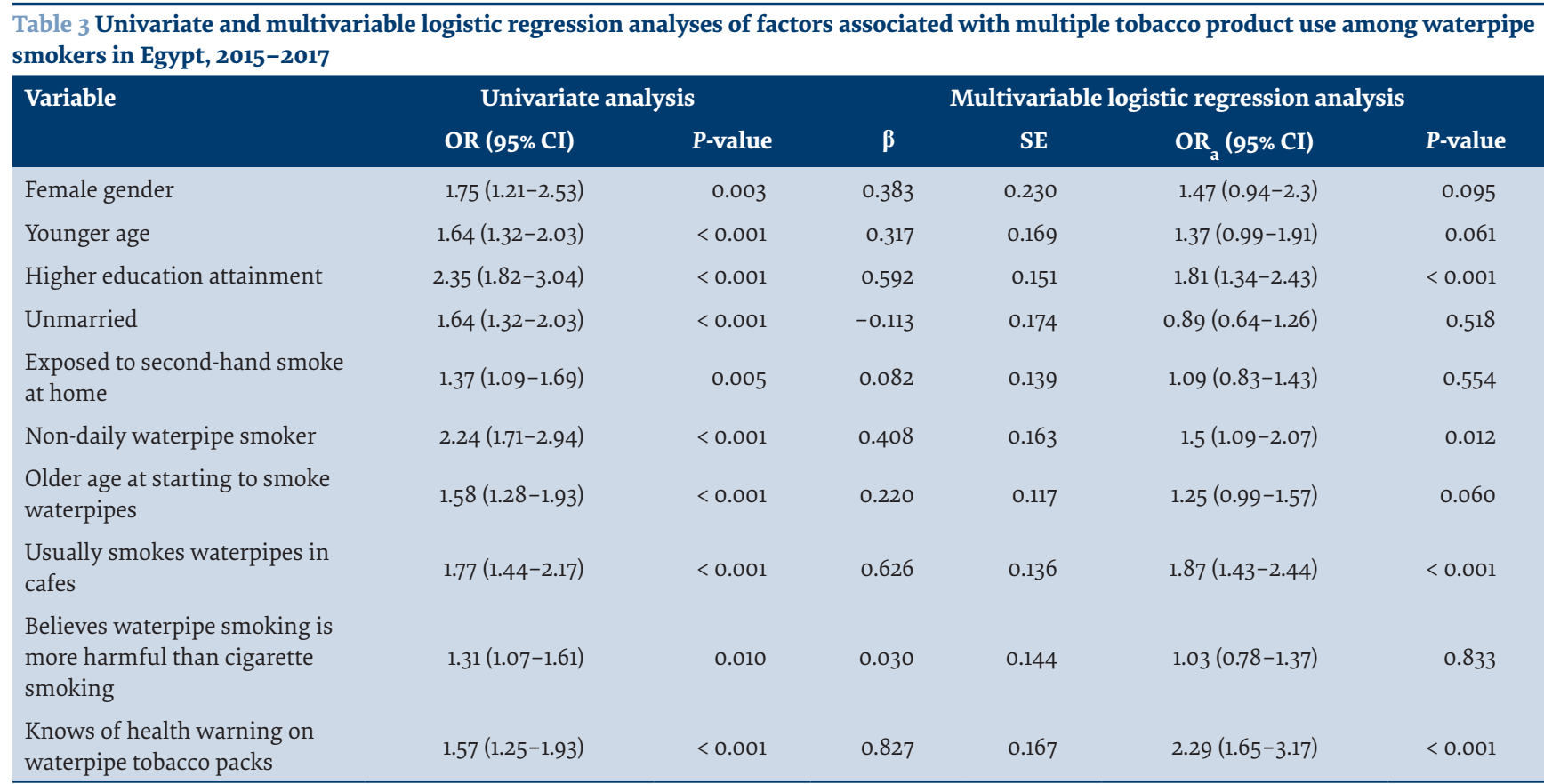

$\mathrm{OR}=$ odds ratio; $\mathrm{CI}=$ confidence interval; $\mathrm{SE}=$ standard error; $\mathrm{OR}_{a}=$ adjusted odds ratio. 
tobacco type was started. Other combinations of multiple use have been observed in the Eastern Mediterranean region (e.g. waterpipe and smokeless) (16) but we did not ask about smokeless use in our study as rates in Egypt for adult smokeless use are low, around 1\% $(26,35)$.

Unique to our study, we asked participants about their awareness of the existing waterpipe tobacco health warnings. Interestingly, we found that knowledge of waterpipe tobacco health warnings was a significant independent predictor of multiple use, and highly correlated with a positive change in the waterpipe smoking habits of participants (reduction in the number of hagar smoked, foregoing a smoke, being more likely to consider quitting). Multiple users in this case may have shifted to other tobacco products in an attempt to quit or because they were under the impression that they were smoking a "lighter" form of tobacco (20-22). We also found that the use of flavoured tobacco did not predict multiple use, as also reported in a US study (11).

Higher educational attainment was also a significant determinant of multiple use in our study. This could be partly explained by the large number of women in the higher educational categories in our participants, thus the link with increased rates of multiple use in this group. This finding is consistent with a previous study in Egypt that found a higher level of cigarette smoking among female participants with a university or higher educational level (29). The authors attributed this to targeted marketing strategies that aim to associate smoking with a liberated identity among female consumers in this group (29).

Another determinant of multiple use was smoking usually at cafes, which was also observed in another study that reported multiple tobacco use in $40 \%$ of bar patrons (9). Multiple users may not be as addicted to waterpipe tobacco smoke as waterpipe-only users, who have a device at home and smoked equally at home or at a cafe. Nonetheless, non-daily waterpipe smoking in our study was a predictor of multiple use, which concurs with a previous study that reported that dual waterpipe and cigarette smokers had fewer waterpipe sessions per week (19).

To maintain a continuous demand for their products, the tobacco industry targets potential new users and vulnerable groups, such as youth and women, with constantly evolving tobacco forms (26). The industry persuades smokers who intend to quit to select products promoted as being of lower risk (20-22) and possible to use in smoke-free environments $(11,26)$. These illusions encourage the use of multiple tobacco products and ignore the evidence of the associated risks $(22,30)$. Wideranging tobacco-free strategies are needed to counter these tactics of the tobacco industry.

Our study had some limitations. It was based on a nonrandom sample which focused on waterpipe smokers, therefore the proportions for multiple tobacco product use in this subset may not represent the Egyptian population of smokers. Tobacco use was based on self-reporting and we did not ask respondents on the frequency or time of starting to use other tobacco products. In addition, because of the cross-sectional nature of the study design, we could not determine whether multiple tobacco product use among our participants was an attempt to quit or identify if there was a shift from one product to another.

\section{Conclusions}

Almost half of the current waterpipe smoker participants used multiple tobacco products. Multiple users were more likely to be younger than waterpipe-only users. Young adult female waterpipe smokers used ENDS significantly more than males. Non-daily waterpipe tobacco smoking, cafes being the usual place of smoking, higher educational attainment and knowledge of the pictorial health warnings on waterpipe tobacco packs were independent predictors of multiple tobacco product use. Our findings are exploratory and may be a basis for future investigations into the rate and frequency of this emerging behaviour. Studies that include possible tobacco product combinations are warranted to guide the expansion of policies to regulate non-cigarette products. Novel warnings and tailored interventions for young adults, especially females, are necessary to curb the simultaneous use of different tobacco products.

\section{Acknowledgements}

The authors are grateful to the participants of this study. We also thank our field team and field supervisor $\mathrm{Mr}$ Raafat Gamal, data interviewers, data managers and data entry personnel for their dedication and adherence to quality during data collection.

Funding: The study was funded by the International Development Research Center through the Tobacco Control Research Group of the American University of Beirut to study waterpipe tobacco smoking prevention and intervention programmes in the region as a part of the project "Shaping Research for Health in the Arab World: a Systems and Network Approach to Advance Knowledge, Inform Policy, and Promote Public Health" (Award 102518).

Competing interests: None declared. 


\section{Consommation de différents produits du tabac chez les jeunes adultes fumeurs de pipe à eau en Égypte}

\section{Résumé}

Contexte: La consommation de différents produits du tabac constitue une tendance émergente. Les études sur la consommation de différents produits du tabac parmi les fumeurs de pipe à eau sont en nombre limité.

Objectifs : La présente étude avait pour objectif d'évaluer la proportion des autres produits du tabac utilisés par les fumeurs adultes de pipe à eau en Égypte, ainsi que d'identifier les déterminants de la consommation de différents produits du tabac.

Méthodes : Des études populationnelles ont été conduites à l'aide de questionnaires d'entretien entre 2015 et 2017 dans le Caire urbain et dans la zone rurale de Menoufia. Les participants âgés de 18 ans ou plus étaient sélectionnés sur la base d'un échantillonnage dirigé non aléatoire par quotas. L'échantillon total incluait 2014 participants. Nous avons analysé les données de 1490 fumeurs de pipe à eau. Les variables enregistrées étaient le tabagisme, les croyances en matière de santé, les comportements en matière de consommation de tabac par pipe à eau, les caractéristiques socio-démographiques, et l'efficacité perçue des mises en garde sanitaires illustrées sur les paquets de tabac pour pipe à eau. Les fumeurs de pipe à eau ont été classés en deux catégories : les fumeurs de pipe à eau exclusifs et les fumeurs consommant différents produits du tabac.

Résultats : Près de la moitié $(44,9 \%)$ des fumeurs de pipe à eau consommaient différents produits du tabac; $93,4 \%$ étaient des consommateurs doubles et 6,6\% des polyconsommateurs. Les autres produits du tabac utilisés étaient les cigarettes $(86,4 \%)$, les inhalateurs électroniques de nicotine $(7,0 \%)$ ou les deux ensemble $(6,6 \%)$. Les consommateurs de différents produits du tabac étaient davantage susceptibles d'être plus jeunes que les consommateurs de pipe à eau exclusifs. Les jeunes femmes adultes consommatrices de tabac par pipe à eau utilisaient 12 fois plus les inhalateurs électroniques de nicotine que les jeunes hommes adultes ( $48,8 \%$ contre $4,1 \%$ respectivement). La consommation non quotidienne de tabac par pipe à eau, ayant lieu le plus souvent dans des cafés, un niveau d'éducation supérieur et la connaissance des mises en garde sanitaires illustrées constituaient des facteurs prédictifs indépendants de la consommation de différents produits du tabac.

Conclusion : Selon notre étude, le consommation de différents produits du tabac était courante parmi les fumeurs de tabac par pipe à eau. Des interventions visant à s'attaquer au problème de la consommation de tabac autre que les cigarettes et de la consommation de différents produits du tabac, notamment chez les jeunes adultes, sont requises de toute urgence.

$$
\begin{aligned}
& \text { تعاطي منتجات متعددة من التبغ في صفوف مدخني الشيشة الشباب في مصر } \\
& \text { آية مصطفى، مصطفى الحسيني، عائشة أبو الفتوح } \\
& \text { الخلاصة إهلا } \\
& \text { الخلفية: ثمة اتجاه متز ايد لتعاطي منتجات متعددة من التبغ. و لا يو جد سوى عدد محدود من الدراسات المتعلقة بتعاطي منتجات متعددة في صفوف } \\
& \text { مدخني الشيشة. } \\
& \text { الأهداف: هدفْنا في هذه الدراسة إلى تقييم نسبة منتجات التبغ الأخرى التي يتعاطاها مدخنو الشيشة البالغون الحاليون في مصر والوقوف على }
\end{aligned}
$$

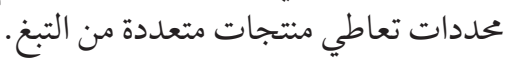

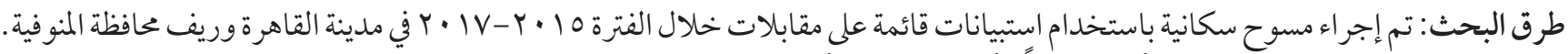

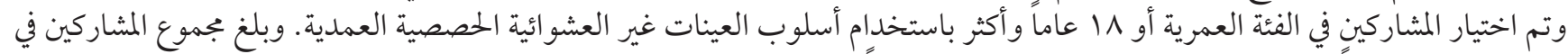

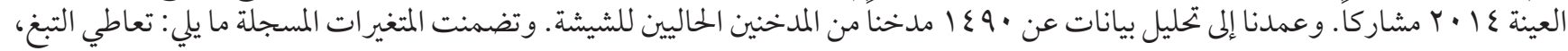

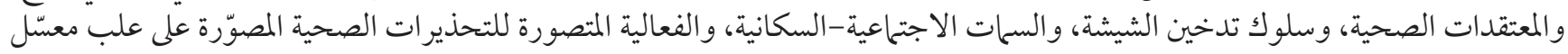

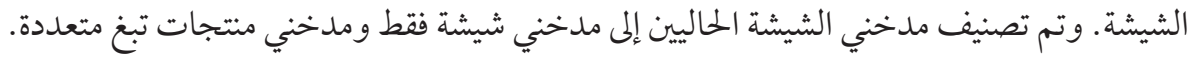

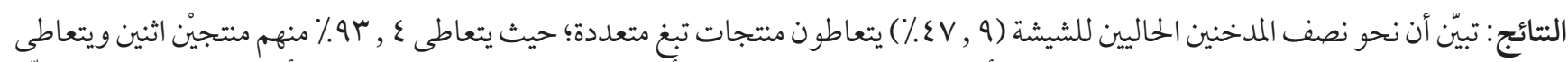

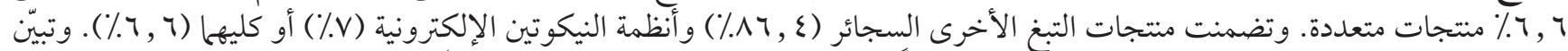

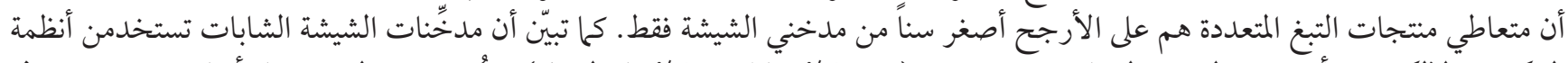

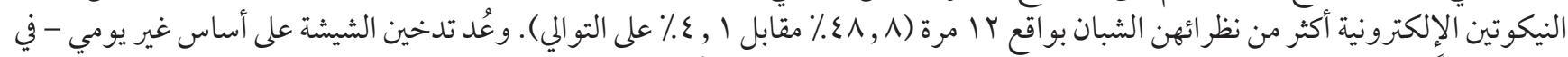

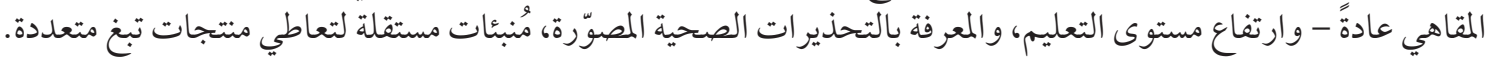

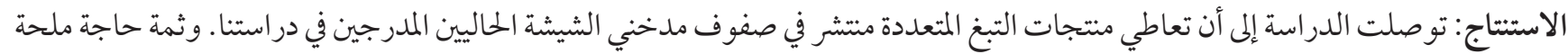

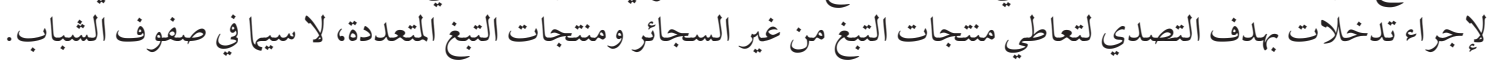




\section{References}

1. Ezzati M, Riboli E. Behavioral and dietary risk factors for noncommunicable diseases. N Engl J Med. 2013 Sep 64-954:(10)369;5. http://dx.doi. org/10.1056/NEJMra1203528 PMID:24004122

2. Noncommunicable diseases. Geneva: World Health Organization; 2017 (http://www.who.int/mediacentre/factsheets/fs355/en/, accessed 9 September 2017).

3. Forouzanfar MH, Afshin A, Alexander LT, Anderson HR, Bhutta ZA, Biryukov S, et al.; GBD 2015 Risk Factors Collaborators. Global, regional, and national comparative risk assessment of 79 behavioural, environmental and occupational, and metabolic risks or clusters of risks, 2015-1990: a systematic analysis for the Global Burden of Disease Study 2015. Lancet. 2016 Oct 724-1659:(10053)388;8. http://dx.doi.org/10.1016/S-0140 8-31679(16)6736 PMID:27733284

4. Sustainable development knowledge platform. Sustainable development goal 3. Progress of Goal 3 in 2017 . United Nations; 2017 (https:// sustainabledevelopment.un.org/sdg3, accessed 9 September 2017).

5. Agaku IT, Filippidis FT, Vardavas CI, Odukoya OO, Awopegba AJ, Ayo-Yusuf OA, et al. Poly-tobacco use among adults in 44 countries during 2012-2008: evidence for an integrative and comprehensive approach in tobacco control. Drug Alcohol Depend. 2014 Jun 70-139:60;1. http://dx.doi. org/10.1016/j.drugalcdep.2014.03.003 PMID:24685560

6. Lee YO, Hebert CJ, Nonnemaker JM, Kim AE. Multiple tobacco product use among adults in the United States: cigarettes, cigars, electronic cigarettes, hookah, smokeless tobacco, and snus. Prev Med. 2014 May;9-62:14. http://dx.doi.org/10.1016/j.ypmed.2014.01.014 PMID:24440684

7. Loukas A, Batanova M, Fernandez A, Agarwal D. Changes in use of cigarettes and non-cigarette alternative products among college students. Addict Behav. 2015 Oct;51-49:46. http://dx.doi.org/10.1016/j.addbeh.2015.05.005 PMID:26046401

8. Weaver SR, Majeed BA, Pechacek TF, Nyman AL, Gregory KR, Eriksen MP. Use of electronic nicotine delivery systems and other tobacco products among USA adults, 2014: results from a national survey. Int J Public Health. 2016 Mar;88-177:(2)61. http://dx.doi.org/10.1007/s-015-00038 0-0761 PMID:26560309

9. Kalkhoran S, Padilla JL, Neilands TB, Ling PM. Multiple tobacco product use among young adult bar patrons in New Mexico. Prev Med. 2016 Feb;21-83:16. http://dx.doi.org/10.1016/j.ypmed.2015.11.024 PMID:26666395

10. Kasza KA, Ambrose BK, Conway KP, Borek N, Taylor K, Goniewicz ML, et al. Tobacco-Product Use by Adults and Youths in the United States in 2013 and 2014. N Engl J Med. 53-342:(4)376;26 01 2017. http://dx.doi.org/10.1056/NEJMsa1607538 PMID:28121512

11. Soneji S, Sargent J, Tanski S. Multiple tobacco product use among US adolescents and young adults. Tob Control. 80-25:174;2016. doi: /10.1136/ tobaccocontrolo51638-2014- PMID: 25361744.

12. Gilreath TD, Leventhal A, Barrington-Trimis JL, Unger JB, Cruz TB, Berhane K, et al. Patterns of alternative tobacco product use: emergence of hookah and e-cigarettes as preferred products amongst youth. J Adolesc Health. 2016 Feb;5-181:(2)58. http://dx.doi.org/10.1016/j. jadohealth.2015.10.001 PMID:26598059

13. Nădăşan V, Foley KL, Pénzes M, Paulik E, Mihăicuță Ş, Ábrám Z, et al. Use of electronic cigarettes and alternative tobacco products among Romanian adolescents. Int J Public Health. 2016 Mar;207-199:(2)61. http://dx.doi.org/10.1007/s8-0774-015-00038 PMID:26729271

14. Waziry R, Jawad M, Ballout RA, Al Akel M, Akl EA. The effects of waterpipe tobacco smoking on health outcomes: an updated systematic review and meta-analysis. Int J Epidemiol. 2017 Feb 10.1093 .43-32:(1)46;1/ije/dyw021 PMID:27075769

15. Levy DT, Cummings KM, Villanti AC, Niaura R, Abrams DB, Fong GT, et al. A framework for evaluating the public health impact of e-cigarettes and other vaporized nicotine products. Addiction. 2017 Jan;17-8:(1)112. http://dx.doi.org/10.1111/add.13394 PMID:27109256

16. Siddiqi K, Shah S, Abbas SM, Vidyasagaran A, Jawad M, Dogar O, et al. Global burden of disease due to smokeless tobacco consumption in adults: analysis of data from 113 countries. BMC Med. 194:(1)13;17 08 2015. http://dx.doi.org/10.1186/s2-0424-015-12916 PMID:26278072

17. Hanafy K, Saleh ASE, Elmallah MEBE, Omar HMA, Bakr D, Chaloupka FJ. The economics of tobacco and tobacco taxation in Egypt. Paris: International Union Against Tuberculosis and Lung Disease; 2010.

18. Morton J, Song Y, Fouad H, Awa FE, Abou El Naga R, Zhao L, et al.; GATS Collaborative Group. Cross-country comparison of waterpipe use: nationally representative data from 13 low and middle-income countries from the Global Adult Tobacco Survey (GATS). Tob Control. 2014 Sep;27-419:(5)23. http://dx.doi.org/10.1136/tobaccocontrolo50841-2012- PMID:23760609

19. Jawad M, Lee JT, Millett C. Waterpipe tobacco smoking prevalence and correlates in 25 Eastern Mediterranean and Eastern European countries: cross-sectional analysis of the Global Youth Tobacco Survey. Nicotine Tob Res. 2016 Apr;402-395:(4)18. http://dx.doi.org/10.1093/ntr/ntv101 PMID:25957438

20. Wackowski OA, Delnevo CD. Young adults' risk perceptions of various tobacco products relative to cigarettes - results from the National Young Adult Health Survey. Health Educ Behav. 2016 Jun;36-328:(3)43. http://dx.doi.org/1090198115599988/10.1177 PMID:26304709.

21. Kasza KA, Bansal-Travers M, O’Connor RJ, Compton WM, Kettermann A, Borek N, et al. Cigarette smokers' use of unconventional tobacco products and associations with quitting activity: findings from the ITC4- U.S. cohort. Nicotine Tob Res. 2014 Jun;81-672:(6)16. http://dx.doi. org/10.1093/ntr/ntt212 PMID:24376276

22. Dunbar MS, Shadel WG, Tucker JS, Edelen MO. Use of and reasons for using multiple other tobacco products in daily and nondaily smokers: associations with cigarette consumption and nicotine dependence. Drug Alcohol Depend. 2016 Nov 63-168:156;1. http://dx.doi.org/10.1016/j. drugalcdep.2016.09.005 PMID:27664553

23. Youth and tobacco use. Estimates of current tobacco use among youth. Centers for Disease Control and Prevention; 2017 (https://www.cdc.gov/ tobacco/data_statistics/fact_sheets/youth_data/tobacco_use/index.htm, accessed 9 September 2017).

24. Control and prevention of waterpipe tobacco products. Geneva: World Health Organization Framework Convention on Tobacco Control; 2016 (WHO FCTC/COP/10/7).

25. Maziak W, Nakkash R, Bahelah R, Husseini A, Fanous N, Eissenberg T. Tobacco in the Arab world: old and new epidemics amidst policy paralysis. Health Policy Plan. 2014 Sep;94-784:(6)29. http://dx.doi.org/10.1093/heapol/czto55 PMID:23958628

26. WHO report on the global tobacco epidemic, 2017: monitoring tobacco use and prevention policies. Geneva: World Health Organization; 2017.

27. Egypt Health Issues Survey 2015. Ministry of Health and Population Egypt, El-Zanaty and Associates Egypt, and ICF International; 2015 (https:// dhsprogram.com/pubs/pdf/FR313/FR313.pdf, accessed 9 September 2017) 
28. WHO global report on trends in prevalence of tobacco smoking. Geneva: World Health Organization; 2015.

29. El Awa F, Fouad H, El Naga RA, Emam AH, Labib S. Prevalence of tobacco use among adult and adolescent females in Egypt. East Mediterr Health J. 2013 Aug;54-749:(8)19. PMID:24975361

30. Maziak W, Ward KD, Afifi Soweid RA, Eissenberg T. Standardizing questionnaire items for the assessment of waterpipe tobacco use in epidemiological studies. Public Health. 2005 May;4-400:(5)119. http://dx.doi.org/10.1016/j.puhe.2004.08.002 PMID:15780328

31. Vugrin ED, Rostron BL, Verzi SJ, Brodsky NS, Brown TJ, Choiniere CJ, et al. Modeling the potential effects of new tobacco products and policies: a dynamic population model for multiple product use and harm. PLoS One. 3)10;27 03 2015):e0121008. http://dx.doi.org/10.1371/journal.pone.0121008 PMID:25815840

32. Klesges RC, Ebbert JO, Morgan GD, Sherrill-Mittleman D, Asfar T, Talcott WG, et al. Impact of differing definitions of dual tobacco use: implications for studying dual use and a call for operational definitions. Nicotine Tob Res. 2011 Jul;31-523:(7)13. http://dx.doi.org/10.1093/ntr/ ntro32 PMID:21436298

33. Tucktuck M, Ghandour R, Abu-Rmeileh NME. Waterpipe and cigarette tobacco smoking among Palestinian university students: a crosssectional study. BMC Public Health. 1:(1)18;10 07 2017. http://dx.doi.org/10.1186/so-4524-017-12889 PMID:28693529

34. Jaber R, Madhivanan P, Veledar E, Khader Y, Mzayek F, Maziak W. Waterpipe a gateway to cigarette smoking initiation among adolescents in Irbid, Jordan: a longitudinal study. Int J Tuberc Lung Dis. 2015 Apr;7-481:(4)19. http://dx.doi.org/10.5588/ijtld.14.0869 PMID:25860006

35. Shisha and smokeless tobacco use among university students in Egypt: prevalence, determinants, and economic aspect. A joint report by the Egyptian Ministry of Health and Population and the World Health Organization; 2014. (http://applications.emro.who.int/dsaf/EMROPUB_2014_ EN_1752.pdf?ua=1, accessed 9 September 2017) 